\title{
The Sword Exercises of the British Cavalry: 1796-1858
}

\author{
Henry Yallop \\ Royal Armouries, UK \\ henry.vallop@armouries.org.uk
}

\begin{abstract}
From the late eighteenth century the British military produced official 'fight books' outlining the methods with which the cavalry were to use their swords. As these 'fight books' were military manuals for instructors, designed to turn trainees into effective soldiers they are, for the most part, clear and precise compared to the sometimes esoteric nature of earlier 'fight books'. In addition, as they coincided with the introduction of standard patterns of cavalry swords the exact types of swords employed can be established. Hence, unusually in fight book studies, a full picture of why these works were produced, who they were aimed at, how widely they were disseminated and what exact forms of weapons these precise techniques were to be employed with can be known. The existence of contemporary accounts and other supplementary evidence can also help us understand how such 'fight books' were received and how effectively the theory contained within was borne out in practice on the battlefield. Over the first sixty years of British cavalry sword exercises, the role of cavalry and the threats they faced from other arms and weapon technologies did not drastically alter; but the way they fought with swords, and the swords themselves, did undergo considerable change.
\end{abstract}

Keywords-British Cavalry swordsmanship, British Cavalry swords, John Gaspard Le Marchant, Henry Angelo Junior, Rules and Regulations for the $S_{W o r d}$ Exercise of the Cavalry, Regulations and Instructions for the Cavalty $S_{w o r d}$ Exercise

\section{INTRODUCTION:}

Until the late eighteenth century there was no centrally imposed or standardised method of sword fighting in the British Cavalry. Indeed there remains little evidence that cavalry swordsmanship was formally considered at all before this time, despite the fact that since the formation of the modern British Army the sword was considered the cavalry's main battlefield weapon. Works on the British cavalry, their type, drill, mounts, horsemanship, use and equipage were written over this period and either disseminated centrally as standing orders and official regulations or privately published. Yet such official works make no mention of the use of swords beyond the method for drawing and returning swords, how to manage them when using pistols, or the position they are to be held in 
when the horse moves at different speeds. ${ }^{1}$ This lack of direction is in stark contrast to instructions regarding firearms in such works, the use of which was heavily prescribed. Rare private works that mention cavalry swords and swordsmanship do so in scant detail. In Astley's chapter "Observations on the Use and Formation of Dragoon Swords" he merely states that the sword be "sufficiently sharp" with the cavalryman "properly skillful in the use of it, and the management of his horse". ${ }^{2}$ How such skill was to be acquired and what, if any, system was to be used in developing the necessary competence is not mentioned. Even Lonnergan's The Fencer's Guide contains little in the way of specific instruction in cavalry swordsmanship. Despite claiming to contain "particular lessons for the Gentlemen of Horse, Dragoons, and Light Horse, or Hussars" these amount to less than 10 pages of a 250 pages work, and are more general observations on cavalry combat. ${ }^{3}$ Seemingly the use of swords, as well as the precise nature of the swords themselves, ${ }^{4}$ was determined at regimental level - rather than centrally imposed, in the way firearms usage was. Any sword training was perhaps determined by the preferences of each regiment's successive colonels (if they had an interest in such matters), those responsible for skill-atarms, or perhaps (as the absence of evidence might suggest) formed no part of formal training at all. Hence in addition to the great variety of types of swords that were in use by the British cavalry during the eighteenth century there could have been an even greater variety in the methods of use of these swords and the amount of training dedicated to swordsmanship at different times, in different regiments, and perhaps even amongst different individuals.

\section{JOHN GASPARD LE MARCHANT:}

However this was to change as a result of the efforts of John Gaspard Le Marchant (17661812). A career soldier and a true military reformer, Le Marchant was committed to improving the efficiency of the British Army. Blessed with royal favour following his command of King George III's escort, Le Marchant eventually established the Royal Military College at High Wycombe and the Army Staff College, Camberley, to his end of producing properly trained officers. ${ }^{5}$ He also wrote on military horsemanship, staff matters and outpost duties. However in the context of 'fight books' it is his 1796 Rules and Regulations for the Sword Exercise of the Cavalry which is most important; a work he devised after observing the superior swordsmanship of the Austrian cavalry in Flanders. ${ }^{6}$ By

\footnotetext{
${ }^{1}$ Bland, Treatise of Military Discipline; Hinde, Discipline of Light-Horse; War Office, Rules and Regulations for the Cavalry, 1795.

2 Astley, Remarks, p. 30. Good horsemanship was fundamental to fighting effectively from the saddle in any period, but such a topic lies outside the scope of this article.

${ }^{3}$ Lonnergan, The Fencer's Guide, pp. iii, 229-238.

${ }^{4}$ Robson, Swords, p. 4.

5 Defence, Major-General Le Marchant.

${ }^{6}$ Le Marchant, Memoirs, pp. 32, 44-45.
} 
making use of his royal patronage Le Marchant was able to have his Exercise approved, centrally issued and widely disseminated, ${ }^{7}$ providing the whole of British cavalry with their first specific treatise on swordsmanship: their first centrally standardised 'fight book'.

\section{1796, RULES AND REGULATIONS FOR THE SWORD EXERCISE OF THE CAVALRY:}

Although perhaps alien to modern eyes in some of its fundamentals, most notably its emphasis on cuts delivered from the wrist with a straight arm, Exercise is for the most part clear and simply explained. Special attention and detail is provided on the specific motions where particular care is required, such as the importance of, and correct method, to "carry the edge" when cutting. ${ }^{8}$ In such respects the work seems well suited for its ultimate audience. The majority of trainees that would be taught the Exercise would be enlisted men with little or no prior experience of swordsmanship. Hence Exercise has the air of a work designed by a solider rather than a fencing master for this particular purpose: to instil, during a time of war, a defined system of swordsmanship into all British cavalrymen in order to turn potentially poor and unschooled swordsmen into ones of at least a standard level of ability and effectiveness. Indeed, Le Marchant was taking steps to ensure this before his Exercise was even published in December 1796 as, after receiving the approval of Horse Guards and the Commander-in-Chief (the Duke of York) in October 1796, he had been running a series of training schools to disseminate his Exercise. Over a period of six months each cavalry regiment sent an officer and twenty men to be schooled intensively for two weeks, after which they would return to their regiment to pass on what they had learnt. ${ }^{9}$

The 1796 published Exercise wastes little time in getting straight to the point of making cavalrymen into swordsmen and, after very briefly outlining the principles and purposes of the system to instructors, the trainee is immediately ready for training, with sword in hand. No specific warm-up is outlined, it instead being commented that the process "will at first be found extremely irksome" on account of the strain on the wrist, and that the first lessons, the cuts, are for "acquiring a suppleness in the wrist and shoulder; as without this indispensable requisite, no person can become a good swordsman". ${ }^{10}$ The importance of this is stressed again later, it being recommended "Every lesson should begin with suppling the wrist". ${ }^{11}$ Instead of a defined warm-up the order of Exercise implies the trainee should immediately face the target wall square on, in a good approximation of the straight-legged riding style of the period, and with sword in hand. The sword drills are first taught on foot, yet as British dragoons had, despite their name, ceased to generally serve as mounted infantry but were (almost without exception) expected to only use their

\footnotetext{
7 Ibid., pp. 46-48.

${ }^{8}$ Le Marchant, Exercise, pp. 3, 26, 74-76.

${ }^{9}$ Le Marchant, Memoirs, pp. 45-47 and Thoumine, Scientific Soldier, pp. 46-47

${ }^{10}$ Le Marchant, Exercise, p. 3.

11 Ibid., p. 22.
} 
swords when mounted, only movements that can be replicated from the saddle are permitted.

On a wall opposite the trainee, the target is drawn, outlining the six cuts (figure 1) all carried out from the starting "guard" position; with the hilt held in front of the face, above the height of the shoulder with an outstretched arm (figure 2). The cuts are then practiced singly, each comprising three or four movements and ending by bringing the sword back to "guard". After mastering the individual cuts, a short section outlines the small changes necessary to string the cuts together collectively and in numerical order to make "the assault". ${ }^{2}$

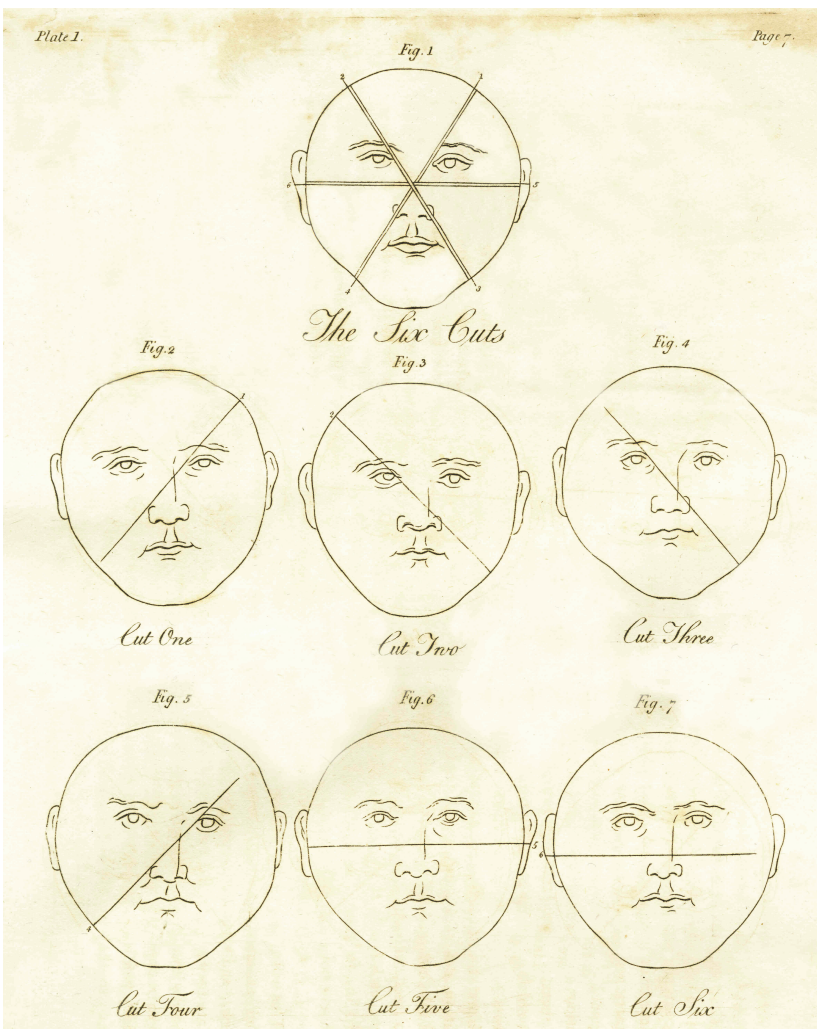

Figure 1: "The Six Cuts" from Exercise (C) Royal Armouries.

${ }^{12}$ Ibid., pp. 25-26. 


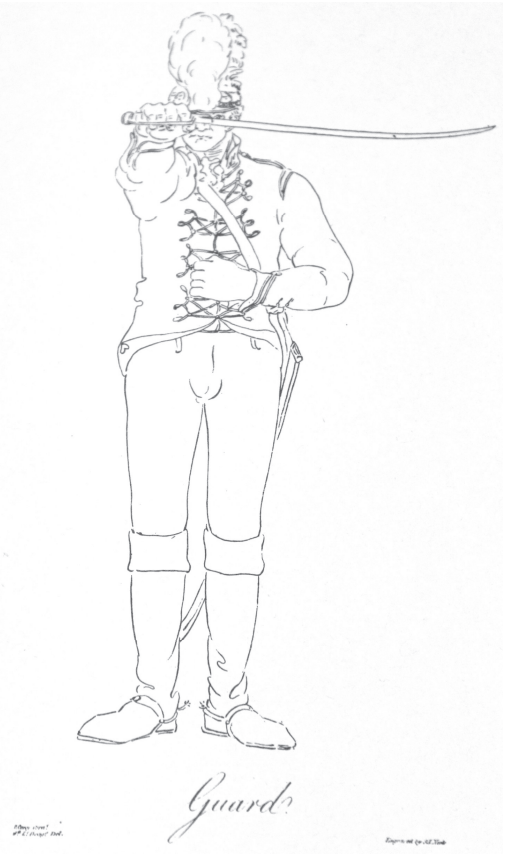

Figure 2: "Guard" from Exercise. (C) Royal Armouries.

It seems that Le Marchant had realised the unusual nature of his proposed system of cutting, as in numerous places he stresses the necessity of not moving anything but the wrist:

In opposing cavalry the arm becomes a pivot, round which the wrist wheels the sword independent of any other action but what may be derived from the shoulder: care must therefore be taken, neither to incline the band to the right or left of the given position, nor to sink it below the level of the antagonist's left ear; but above all, not to bend the elbow: these are faults which beginners are extremely apt to commit, and which expose the sword arm to be completely disabled. The attention cannot be too often recalled to these most essential points in the science: the strict observance of which chiefly constitutes the excellence of the system. ${ }^{13}$

The necessity of keeping the sword aimed at the left ear of opposing cavalry, with the shoulder only being used to take the hand to the start position of the cut - which is then executed by the wrist alone - is again stressed in the same terms in "Application of the Edge" 14 and as a footnote marked with an asterisk in the section dealing with the cuts collectively. Here further clarity is provided as to the lack of motion required from the

\footnotetext{
13 Ibid., p. 16.

14 Ibid., p. 75.
} 
arm/shoulder in cutting: "It should always be remembered that the force of the stroke against a person on their own level, [i.e. cavalry] must be derived from the sweep of the blade, and not from the motion of the arm." 15 This is further reinforced in the details of the specific and constituent movements of each cut where it is "the sole action of the wrist" that directs the blade in any of the three or four motions that make up cuts I-VI (figure 3). ${ }^{16}$

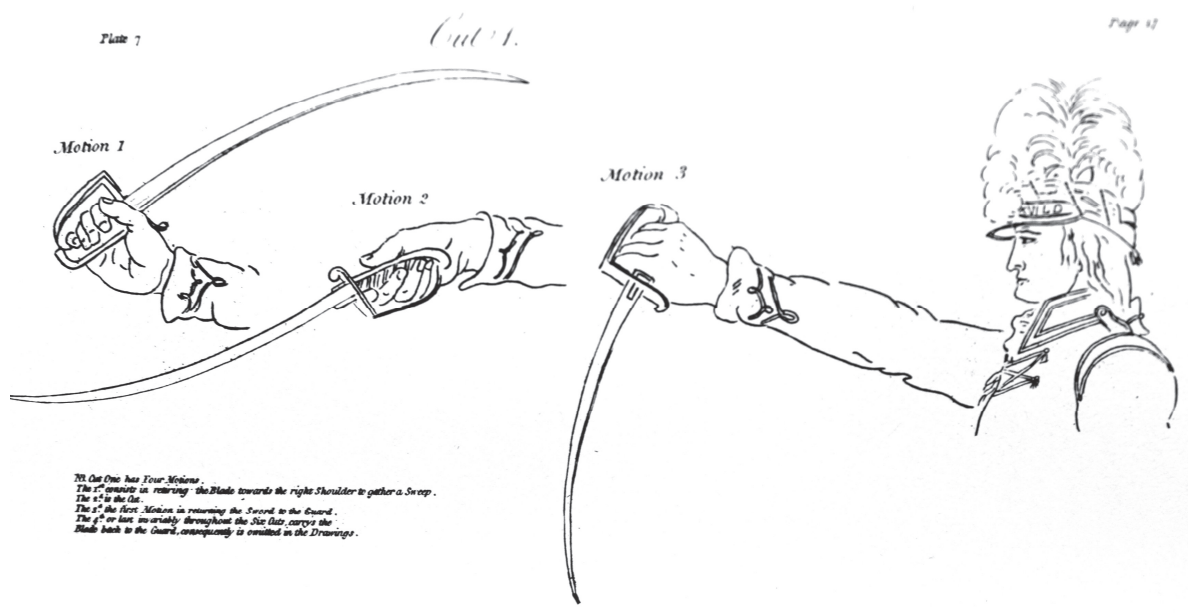

Figure 3: Cut I in four motions (the $4^{\text {th }}$ being returning to "Guard") from Exercise. Showing the specific wrist actions detailed for cutting. (C) Royal Armouries.

The section "Modes of Parrying" next introduces the eight protects (parries), five of which (including the starting "guard" position) are intended for protecting the front. Where possible the back/spine of the blade is used to parry, something emphasised in both the section regarding facing bayonets of the infantry and reinforced when meeting "the enemy's sabre" of opposing cavalry. ${ }^{17}$ The first parry, "Left protect", (figure 4) involves carrying the blade left from the "guard" across the body with a straight arm, bringing the point up and changing hand position by placing the thumb on the right/outside of the grip between the backpiece, ear and langet during this movement so that the back/spine of the blade is used to meet the opponent's blade, with the knuckleguard facing towards the user. ${ }^{18}$ "Right protect" is not described from the "guard" but only from "left protect" and involves carrying the straight arm to the right so that the back/spine of the blade is again used to make the parry, with the knuckle-guard still

\footnotetext{
15 Ibid., p. 26.

16 Ibid., pp. 17-25.

17 Ibid., pp. 7 , 28-9.

18 Orientation of the sword is described as if the sword is held in the right hand with edge to the front and point upwards. Directly to the front, over the horse's head, is described as 12 o'clock, directly the rear as 6 o'clock etc.
} 
towards the user. Neither of "Left" or "Right" protect is intended as a fixed parry but both should be used on either side of the horse, with which "protect" being used depending "on the direction of the cuts or thrust which they intend to parry". Used in this way, "Left Protect" and "Right protect" could parry attacks from between 9 and 6 o'clock.

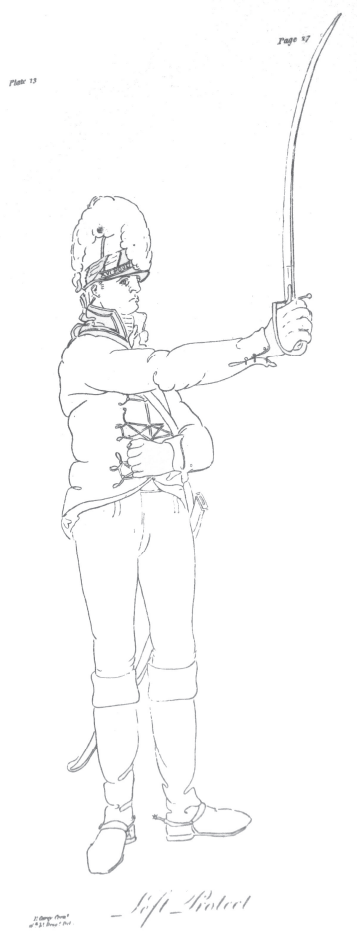

Figure 4: "Left Protect" from Exercise. Note the back/spine of the blade is used to make the parry. (C) Royal Armouries.

Parrying with the back/spine of the blade is not deemed possible with "horse, near side protect" as the edge "must necessarily be exposed from the nature of the guard". ${ }^{19}$ The fifth frontal guard, "horse, off side protect" is another movement only described from the previous position. Demanding "the exact position of right protect" it in fact appears (although unillustrated) to be nothing more than "Right protect" directed toward the

${ }^{19}$ Ibid., p. 29-30. It is probable that "guard" in this context refers to the position of the motion rather than the nature of the stirrup-hilt. Although the term could apply to both, the nature of the knuckle-guard on the stirrup-hilt means the edge must be uppermost for the knuckle-guard to provide protection to the front when the sword is held in this position. However this is clearly not a concern with "Left" or "Right Protect" where parrying with the back/spine of the blade leaves the fingers unprotected by the knuckle-guard. 
horse's right ear, the 1 o'clock position, and like "Right protect" uses the back/spine of the blade to parry with. ${ }^{20}$

The three rear parries follow and are taught only sequentially, so only the first of these, "bridle-arm protect", is described from the "guard". As with some of the frontal guards this seems strange, as in action the need to take them singly would surely arise. "Swordarm protect" follows and then "St George, or head protect" which is intended only to cover the rear of the head, the front being protected by "guard". All three of these rear protects offer the edge of the blade instead of the back/spine for the parry, "in order to bring the mounting [the sword's knuckle-guard] in a proper direction to protect the hand". ${ }^{21}$ After this sequence of three rear parries, "the rear cut" follows (in order to strike back against the enemy behind which has necessitated the rearward parries) in a similar manner to cut VI. Yet again this action is only outlined from the "St George", when in action it could be necessary to riposte with "the rear cut" after either of the other two rearward parries.

The final constituent part of the Exercise deals with the application of the point. Thrusts are of much less importance than cuts in Exercise, it being recommended they only be used against a retiring enemy or their flank. This lack of focus on the thrust is demonstrated by there being just three points, compared to six cuts. To an even greater extent than the parries, these three thrusts each comprise a linked sequence of moves, without instruction on how to execute them in isolation or a different order. All the thrusts require a change of grip, facilitated by the new sword that was designed for Exercise. ${ }^{22}$ This involves putting the thumb along the backpiece; the forefinger down the right/outside of the grip and langet, in line with the flat of the blade; with the head of the backpiece cupped in the palm (figure 5). Having done so, the first thrust, "left give point" is directed diagonally down, as if aimed at infantry. As part of the same sequence "to the rear, parry" immediately follows. The language is not particularly clear and the movement is unillustrated but it seems to consist of; withdrawing the hand until it is level with the left ear (when the head is looking left); at the same time as dropping the point so the blade hangs straight down, covering the torso at the 9,8 or 7 o'clock positions - with the edge and stirrup-guard facing outwards to the left rear. Although no grip change is stipulated, when "the blade becomes perpendicular", there is an opportunity for the thumb and forefinger to resume their normal position on the grip, wrapped round the ferrule. Finally cut IV is executed from this parrying position, a motion that finishes in "guard" and completes the "left give point" sequence of thrust; parry; cut; guard.23

\footnotetext{
${ }^{20}$ Ibid., pp. 29-30.

${ }^{21}$ Ibid., p. 31.

22 Yallop, 'A Sword', pp. 220-23.

${ }^{23}$ Le Marchant, Exercise, pp. 36-7.
} 


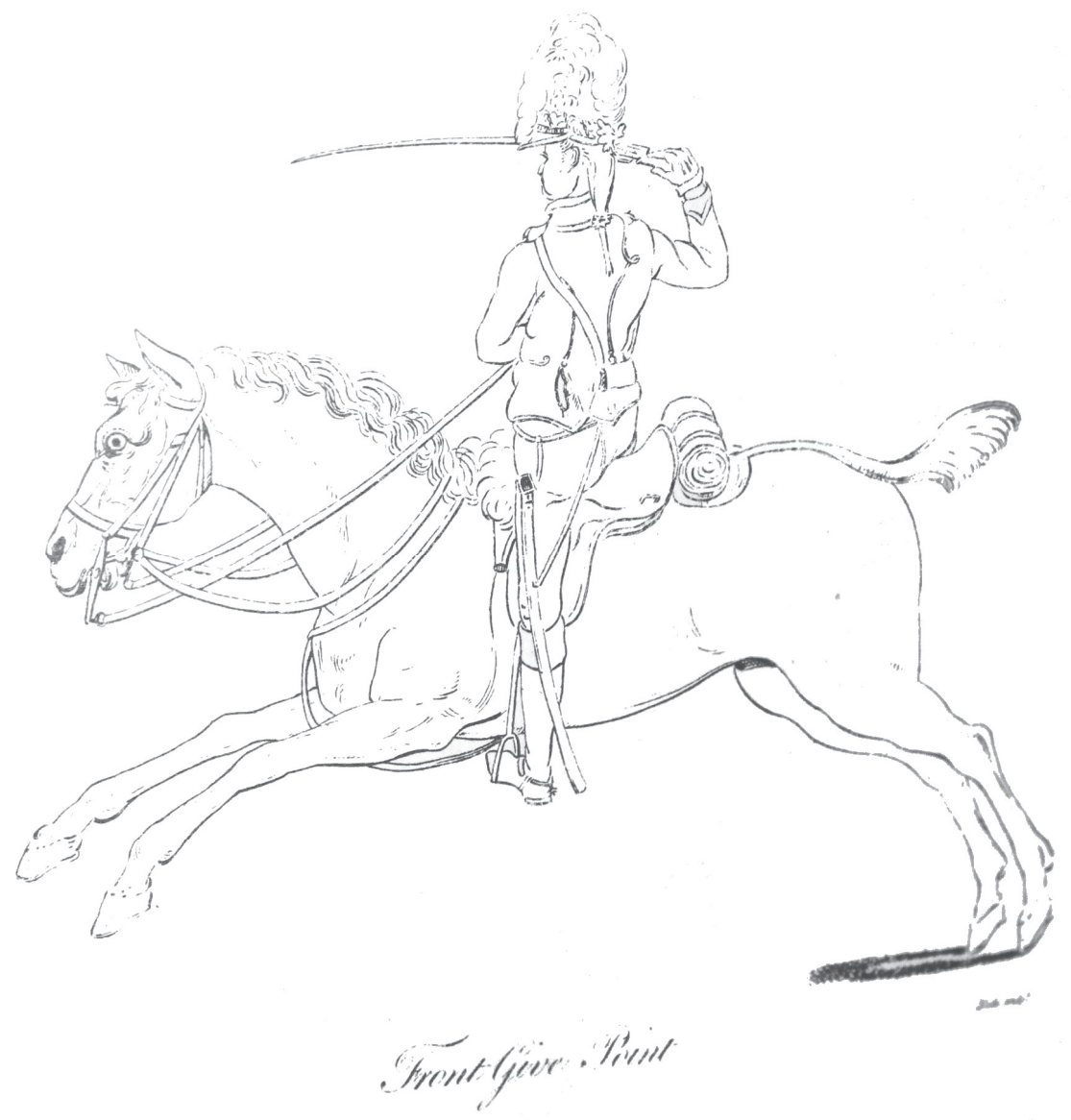

Figure 5: "Front Give Point" from Exercise. Note the right shoulder is drawn back and the sword cupped in the palm. (C) Royal Armouries.

"Front give point" is the only thrust intended to be used against opponents at the same height (cavalry). With the same thrusting-grip (blade edge to the right/outside) this involves twisting from the waist to the right whilst taking the hand back as far as possible in a straight line and above the level of the eye (see figure 5), before darting the hand directly forward while twisting the torso to the left for maximum extension of the point forward, whilst keeping the torso upright. Two cuts immediately follow: cut V and VI. Although again not explicit in changing from the thrusting-grip, in stipulating that when bringing the blade to the right after making the "front give point" the "back of the hand" is brought "under", this provides a chance for the cutting-grip of forefinger and thumb around the ferrule to be resumed to better execute the cuts that follow. ${ }^{24}$

${ }^{24}$ Ibid., p. 38. 
"Right give point" is executed much the same as "left give point" and is also intended to be performed against infantry. However it is followed by just a single parry. After making the thrust, and confusingly in order to make the following "rear parry", the blade is carried forward "to gather a sweep". ${ }^{25}$ During this motion the edge of the blade is brought "up, and the back of the hand under", the purpose (although again not stated) of such a motion is presumably to enable the grip to be changed from the thrusting grip and enable the knuckle-guard to cover the hand. ${ }^{26}$ The instructions are again somewhat unclear and lacking in illustrations for this parry, but it seems that the arm should be carried as far to the rear as possible with the hand at the level of the shoulder and blade pointing down. In theory this would parry an attack from below (this sequence being for fighting infantry) aimed at the rider's right torso, below the level of the shoulder: essentially guarding between his 2 and 5 o'clock positions during this movement.

Training then progresses to the "Sword Exercise on Foot" where trainees perform a series of actions combining cuts, guards and points, termed as a division. Three of the six divisions begins with cuts I-VI, "the assault" as the first action, representing the crucial charge, followed by a set series of motions appropriate to the theoretical combat situation. These include both successful and failed attacks against cavalry (whereby a pursuit is followed by points or a retreat is accompanied by rearward parries and cuts); defence against multiple opponents and attacks against infantry in a variety of settings.

Confusingly however, two new parries are introduced here without illustration. The first of these "On your right to the front parry" appears to be a variation on "right protect", but is introduced in a "division", the fourth, simulating engaging enemy infantry. ${ }^{27}$ To make the parry, instead of carrying the blade from the "guard" to the right and rear with the point up as in "right protect", the edge is carried horizontally until the arm can move backwards no more, at which point the wrist is bent back and the blade turned point up, with the edge to the rear. From this position the parry to the front with the back/spine of the blade leading is made, covering from the 5 o'clock position to potentially as far as 11 o'clock. The second new parry, "Left parry" is also intended for defending against infantry and comes in the "Sixth Division of Movements". It involves placing the hand "in the hollow of the [left] shoulder", dropping the point down and back on the left side as far as possible and, with the point down, "making a circle by bringing it round to the front in the same position". ${ }^{28}$ This is clearly intended to parry attacks aimed below the shoulder (as attacks from infantry invariably would be) from roughly the 7 o'clock to 11 o'clock position.

Once mastered on foot, trainees are mounted and the "Six Divisions" are performed at a walk, with some extra commentary on equestrian matters and body position, stressing the

\footnotetext{
25 Ibid., p. 39.

26 Ibid.

${ }^{27}$ Ibid., p. 53.

28 Ibid., p. 57.
} 
need to keep an erect and balanced torso. Subsequent stages involve performing the motions while moving in a circle, representing the constant turning of the cavalry melee, before increasing speed. Only then are trainees introduced to specific targets, through the introduction of "running at the ring" to practice points and the "edge post" for cuts; it being recommended that a series of these at a varying heights and on both sides be laid out on a course for trainees to practice against. Finally, opposition is introduced, with mounted trainees facing off against each other for the "Attack and Defence in Line". They form line, the main cavalry formation throughout the period, and make two divisions of prescribed attacks, with matching defences, before performing a final simulation of the pursuit. Yet even in this final stage of Exercise a new parry is introduced. A slight variation of "Right protect" it is not given a different name in the text but is illustrated as "Thigh Protect". In essence this is simply "Right protect" but with "the hilt of the sword resting on the knee" so as to guard a lower line of attack. ${ }^{29}$

As the author of this article has previously suggested, it seems that one of the two types of sword used with Exercise, the Pattern 1796 Light Cavalry sword (figure 6), was specifically designed to suit the requirements of Exercise. ${ }^{30}$ With sufficient "suppling the wrist" it is possible that this light, curved sword could be used successfully with this system of the wrist, second, third and fourth fingers providing impetus to the cut. However, it is difficult to see how this method of cutting from the wrist would be as easy, or successful, with the different form of the longer, heavier and differently balanced Pattern 1796 Heavy Cavalry sword (figure 7). ${ }^{31}$ In addition to the issues of cutting with the sword it would also be more problematic to use the Heavy Cavalry sword for the methods of parrying and thrusting in Exercise. Although having a slightly longer grip than the Light Cavalry sword, the grip of the Heavy Cavalry sword is still too short to enable the parrying grip of "Left protect" and "Right protect", with the thumb on the grip between backpiece, ear and langet to be taken comfortably. Nor is there the possibility, as with the Light Cavalry sword, of making this grip more comfortable and secure by allowing the thumb to fall on the langet, ${ }^{32}$ as not only are the langets of the Heavy Cavalry sword much smaller and rounded but, more importantly, the hand's access to the langets is completely prevented by the disc-shaped guard in front of the hand. This guard also prevents the finger extending onto the langet when the thrusting grip is taken, as is possible with the Light Cavalry sword. ${ }^{33}$ Hence when using the Heavy Cavalry sword in order to comfortably extend the finger along the side of the grip, as outlined in Exercise

\footnotetext{
${ }^{29}$ Ibid., p. 80.

30 Yallop, 'A Sword', pp. 220-8.

31 Those Heavy Cavalry swords that have undergone substantial modifications (the removal of the inside of the guard, langets and the spear pointing and subsequent shortening of the blade) are slightly lighter and seemingly slightly better balanced for wrist cutting.

32 Yallop, 'A Sword', p. 222-223.

33 Ibid.
} 
for giving point, the hand has to rest far toward the end of the grip, producing a rather unstable hand position where the palm cannot securely cup the head of the backpiece.

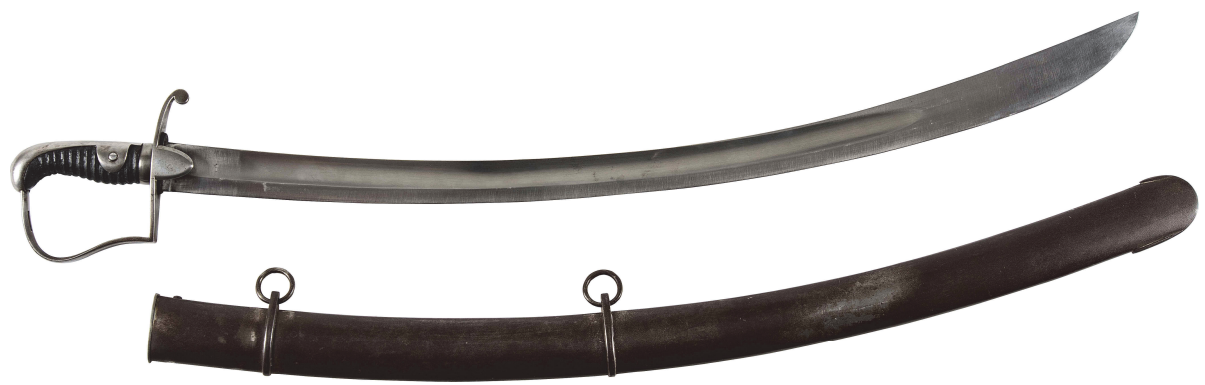

Figure 6: Pattern 1796 Light Cavalry Trooper's sword \& scabbard. Inventory no. IX.245. (C) Royal Armouries.

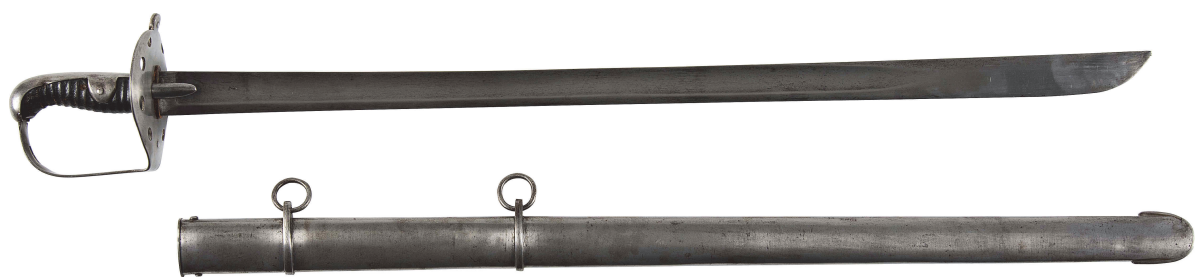

Figure 7: Pattern 1796 Heavy Cavalry Trooper's sword \& scabbard. Inventory no. IX.2710. (C) Royal Armouries.

This raises the question of to what extent did the British cavalry, especially the heavy regiments, adhere to Le Marchant's Exercise? Certainly the contemporary accounts that go into sufficient detail suggest that in practice cuts were not always delivered by the wrist alone, even when facing cavalry. It would be almost impossible to cause the kind of wounding described when limbs, heads and even brass helmets are cut through in a stroke with a cut from the wrist alone, and some of these accounts certainly imply a great blow falling rather than a quick wrist cut. ${ }^{34}$ Perhaps Exercise's system of controlled wrist cutting was hard to keep to in stressful combat situations, even for those light cavalry armed with an appropriate sword. Some French accounts do imply both light and heavy British cavalry cut with larger, more dramatic motions than the controlled cuts of Exercise. ${ }^{35} \mathrm{It}$ seems probable therefore that both heavy and light cavalry (albeit given the nature of their sword the heavy cavalry perhaps more frequently) did also cut from the shoulder with a straight arm as well as (in combination with, or instead of) solely from the wrist.

34 Ibid., p. 228-229.

35 Lieutenant Chevalier, Sounvenirs des guerres napoléoniennes, p. 323, cited in Field, Waterloo: The French perspective, p. 145 \& Parquin, Military Memoirs, p. 143. 
Indeed, despite repeatedly specifying the wrist alone should be used to drive the cuts ${ }^{36}$ there is room to misunderstand this directive. In the section "I. Cuts" Exercise speaks of "The action of the wrist and shoulder alone directs the blade" and perhaps again implies the role of the shoulder combining with the wrist in cutting when stressing the importance of "giving motion to the arm by means of the wrist and shoulder without bending the elbow". ${ }^{37}$ Certainly this combined cutting with wrist and shoulder together appears to be how some chose to interpret the cutting method of Exercise. ${ }^{38}$ Possibly such an interpretation was practiced more widely, leading to the above accounts and providing the heavy cavalry with a more suitable method of using their sword with Exercise? Perhaps modifications to, or clarifications of, Exercise were passed on orally at Le Marchant's training schools (see footnote 9) and subsequently at regimental level? It could be significant that the author of this article has found no clear indication of British cavalry cutting with a bent elbow against cavalry, something that Exercise forbade "above all", 39 suggesting Le Marchant's system was adhered to where possible with at least the central tenet of keeping the arm straight when cutting being observed.

This supposition about practical modifications and clarifications to Exercise seems to have been confirmed by discovery of a previous unknown sword exercise written for British cavalry. Supposedly published in 1818, no copy was known until the original 1818 handwritten booklet was recently discovered and reproduced. ${ }^{40}$ Its author, LieutenantColonel Radclyffe, outlined two methods of cutting when using the "Six Cuts" of Exercise. The first, recommended only against infantry "receives its impulse from the whole body and its immediate action from the arm" - which appears to mean the elbow and would correspond with Exercise's permitted bending of the elbow against infantry. However, Radclyffe's description of the "second mode" or "cavalry cut" is most illuminating:

In the second mode [cavalry cut], the sword is equally directed by the arm and aided; in its reach, by the inclination of the body; but it receives its immediate impulse from the hand, and its local direction from the wrist. The shoulder is thus a primary and the wrist a secondary pivot, by means of which the blade may be made to move with great rapidity: compared with the former manner [infantry cut], it loses considerably in force; but it gains much in celerity and is secure in its application. ${ }^{41}$

Radclyffe was a heavy cavalryman of considerable practical experience who was on active service throughout the whole of the Napoleonic Wars. Given his role as a Major of Brigade (appointed June 1810) in instructing the cavalry of General Slade's brigade in

\footnotetext{
${ }^{36}$ Le Marchant, Exercise, pp. 16-26.

37 Ibid., p. 2.

38 Wilson, Self-Instructor, pp. $55,32$.

${ }^{39}$ Lee Marchant, Exercise, pp. 2 , 16.

${ }^{40}$ Radclyffe, A New System, pp. 5, 6, 12.

41 Ibid, p. 25.
} 
swordsmanship ${ }^{42}$ it seems likely that this method of cutting from shoulder and wrist together, although recorded in 1818, was in practice being used, at least by the regiments under his influence, well before this date. Furthermore, it would be reasonable to assume, especially given the eyewitness accounts of cutting and wounding referenced above, that such cutting practices were also carried out in other regiments who came to the same practical conclusion as Radclyffe, yet didn't document it as part of a proposed new sword exercise. Yet in its clarity, Radclyffe's work appears to be clear evidence that the wrist alone was not in practice used to drive cuts, even against cavalry, but was a secondary means of propulsion behind the shoulder; at least for the British heavy cavalry who with their form of sword could not practically cut with wrist alone.

Nevertheless, the general combination of swords and system do seem to have been relatively successful, even if adhering to some of the particulars of the latter as originally written in Exercise might not have always been possible. Although in cavalry combat, even more than infantry engagements, there are so many variables that determine success (speed of the charge; cohesion; mount and troop quality; horsemanship; fatigue and morale to name a few) there are occasions that suggest the 1796 swords and 1796 Exercise did combine to provide success on the battlefield. During the Battle of Campo Mayor (25 March 1811) the French cavalry successfully withstood multiple charges from the British on their superior horses and it was only in the melee that the French were broken due to "the superiority of swordsmanship our fellows [the British 13 $3^{\text {th }}$ Light Dragoons] showed." 43 This statement was echoed at the Battle of Fuentes de Oñoro (3-5 May 1811), when French cavalry were once again bested in the melee where swordsmanship told: "Our fellows [the British 14 $4^{\text {th }}$ Light Dragoons] evidently had the advantage as individuals" ${ }^{44}$ and again with the claim that British cavalry during the Peninsular War (1807-14) "were mostly excellent swordsmen". ${ }^{5}$ However, just as there are anecdotal accounts that imply the superior swordsmanship of the British cavalry there are those that imply quite the opposite, claiming the methods of French cavalry, without any centrally imposed sword exercise, were superior to those British trained in Le Marchant's system. ${ }^{46}$ Indeed, one British Heavy Cavalry officer claimed that at Waterloo, the "Guard" position of Exercise had been disadvantageous to his troops in combat, on account of it being unnecessarily tiring to maintain. ${ }^{47}$ Radclyffe went further in his $A$ New System of Cavalry Swordsmanship by levelling a series of serious criticisms at Exercise: namely that it was too defensive, overly complex, too reliant on the cut, and only suitable for use by skirmishers

\footnotetext{
42 Ibid., pp. 5-6.

43 An officer of the $13^{\text {th }}$ wrote of the incident in 'The Courier', 20 April 1811, cited in Fletcher, Galloping, pp. 130 , 141 footnote 12.

44 Francis Hall, Recollections in Portugal and Spain during 1811 and 1812 cited in Muir, Tactics, pp. 125 , 288 footnote 51 .

45 J. M., 'On the Actions', p. 250.

46 Bragge, Peninsular Portrait, p. 49; Vindex, 'Actions of the British Cavalry', p. 363; Chevalier, op. cit. 47 Waymouth, '2nd Life Guards', p. 44
} 
or individuals (theoretically more the role of light cavalry) rather than attacks in line (theoretically more the role of heavy cavalry). ${ }^{48}$ Given these criticism and the symbiotic relationship between the 1796 Light Cavalry sword and Exercise, a relationship lacking between Exercise and the Heavy Cavalry sword, it is not surprising that the above accounts of the swords and system of swordsmanship working well together seem to primarily come from the light cavalry, whereas the criticisms come from the heavies.

However any system of swordsmanship, especially one so widely adopted during such an intense period of conflict, is likely to produce a range of opinions as to its usefulness; yet Le Marchant's original Exercise did remain in official service with the British cavalry for 23 years. Perhaps it should not be surprising that an established system was maintained during a period of war, but with time for reflection and reform during a period of peace change could practically be considered.

\section{HENRY ANGELO JUNIOR:}

There had, however, been modifications made to Le Marchant's Exercise long before it was officially replaced for the regular cavalry in 1819 by Henry Angelo Junr.'s (1780-1852; otherwise known and Henry Angelo the Younger or Angelo III) Regulations and Instructions for the Cavalry Sword Exercise. In order to have a full picture of both the form of the 1819 Regulations and the nature of its authorisation it is necessary to understand a little of these earlier modifications and the Angelos.

Henry Angelo Junr. was the second son of Henry Angelo Snr. (1756-1835; Henry Charles William Angelo or Angelo II) and the grandson of Domenico Angelo (1717-1802; Angelo I) the celebrated fencing and riding master, and hence came from a line of well-established and supremely respected and favoured fencing instructors. ${ }^{49}$ In 1794 Henry Snr. was appointed fencing master of the wealthy, influential, and royally favoured Light Horse Volunteers of London and Westminster ${ }^{50}$ and in 1798-99 Henry Angelo Snr. and Henry Angelo Junr. together devised Hungarian \& Highland Broad Sword as an instructional volume for the regiment. This was based on Le Marchant's approved Exercise but contained numerous additions and some amendments. Several new guards/protects were introduced, illustrated for both mounted and dismounted use, most of which subsequently appeared in Henry Angelo Junr.'s official sword exercises of the 1810s for three branches of the British regular military (Navy, Infantry and Cavalry). See table 1 for how these relate.

\footnotetext{
48 Radclyffe, A New System, pp. 14-15.

49 Aylward, The House of Angelo.

${ }^{50}$ Ibid., p. 169.
} 


\begin{tabular}{|c|c|c|c|c|c|c|}
\hline \begin{tabular}{|c|}
$1798-99$ \\
Hungarian \& \\
Highland \\
Broad Sword
\end{tabular} & $\begin{array}{l}1813 \text { Naval } \\
\text { Cutlass } \\
\text { Exercise }\end{array}$ & $\begin{array}{l}1816 \& 1817 \\
\text { Infantry } \\
\text { Sword } \\
\text { Exercise }\end{array}$ & \begin{tabular}{|l|}
1819 \\
Cavalry \\
Sword \\
Exercise
\end{tabular} & $\begin{array}{l}1835 \\
\text { Sword } \\
\text { Exercise } \\
\text { adapted for } \\
\text { Yeomanry }\end{array}$ & \begin{tabular}{|l}
1840 \\
Cavalry \\
Sword \\
Exercise
\end{tabular} & $\begin{array}{l}1842 / 45 \\
\text { Cavalry } \\
\text { Sword } \\
\text { Exercise }\end{array}$ \\
\hline- & - & - & Engage & Engage & - & Engage \\
\hline $\begin{array}{l}\text { Hanging } \\
\text { Guard }\end{array}$ & - & $\begin{array}{c}\text { [Engaging] } \\
\text { Guard }\end{array}$ & $\begin{array}{l}\text { [Engaging] } \\
\text { Guard }\end{array}$ & $\begin{array}{l}\text { [Engaging] } \\
\text { Left Guard }\end{array}$ & $\begin{array}{l}\text { [Engaging] } \\
\text { Guard \& Left } \\
\text { Engage }\end{array}$ & $\begin{array}{c}\text { [Engaging] } \\
\text { Guard \& Lef } \\
\text { Guard }\end{array}$ \\
\hline - & - & $\begin{array}{c}\text { [Engaging] } \\
\text { Inside Guard }\end{array}$ & $\begin{array}{c}\text { [Engaging] } \\
\text { Inside Guard }\end{array}$ & - & $\begin{array}{c}\text { [Engaging] } \\
\text { Inside Guard }\end{array}$ & $\begin{array}{l}\text { [Engaging] } \\
\text { Inside Guarc }\end{array}$ \\
\hline- & - & $\begin{array}{c}\text { [Engaging] } \\
\text { Outside } \\
\text { Guard }\end{array}$ & $\begin{array}{c}\text { [Engaging] } \\
\text { Outside } \\
\text { Guard }\end{array}$ & $\begin{array}{l}\text { [Engaging] } \\
\text { Right Guard }\end{array}$ & $\begin{array}{c}\text { [Engaging] } \\
\text { Outside } \\
\text { Guard \& } \\
\text { Right } \\
\text { Engage } \\
\end{array}$ & $\begin{array}{c}\text { [Engaging] } \\
\text { Outside } \\
\text { Guard \& } \\
\text { Right Guard }\end{array}$ \\
\hline Inside Guard & $\begin{array}{l}\text { Inside } \\
\text { Guard }\end{array}$ & $\begin{array}{l}1^{\text {st }} \text { Guard or } \\
\text { Inside Guard }\end{array}$ & $1^{\text {st }}$ Guard & $1^{\text {st }}$ Guard & $1^{\text {st }}$ Guard & $1^{\text {st }}$ Guard \\
\hline Outside Guard & $\begin{array}{l}\text { Outside } \\
\text { Guard }\end{array}$ & $\begin{array}{c}2^{\text {nd }} \text { Guard or } \\
\text { Outside } \\
\text { Guard }\end{array}$ & $2^{\text {nd }}$ Guard & $2^{\text {nd }}$ Guard & $2^{\text {nd }}$ Guard & $2^{\text {nd }}$ Guard \\
\hline $\begin{array}{c}\text { Half Circle } \\
\text { Guard }\end{array}$ & Half Circle & $\begin{array}{c}\text { 3rd Guard or } \\
\text { Half Circle }\end{array}$ & $3^{\text {rd }}$ Guard & $3^{\text {rd }}$ Guard & $3^{\text {rd }}$ Guard & $3^{\text {rd }}$ Guard \\
\hline - & - & $\begin{array}{l}4^{\text {th }} \text { Guard or } \\
\text { Outside Half } \\
\text { Circle }\end{array}$ & $4^{\text {th }}$ Guard & $4^{\text {th }}$ Guard & $4^{\text {th }}$ Guard & $4^{\text {th }}$ Guard \\
\hline $\begin{array}{c}\text { Inside Half } \\
\text { Hanger }\end{array}$ & $\begin{array}{c}\text { Inside Half } \\
\text { Hanger }\end{array}$ & $\begin{array}{c}5^{\text {th }} \text { Guard or } \\
\text { Inside Half } \\
\text { Hanger }\end{array}$ & $5^{\text {th }}$ Guard & $5^{\text {th }}$ Guard & $5^{\text {th }}$ Guard & $5^{\text {th }}$ Guard \\
\hline $\begin{array}{l}\text { Outside Half } \\
\text { Hanger }\end{array}$ & $\begin{array}{c}\begin{array}{c}\text { Outside } \\
\text { Half } \\
\text { Hanger }\end{array} \\
\text { Hang }\end{array}$ & $\begin{array}{c}6^{\text {th }} \text { Guard or } \\
\text { Outside Half } \\
\text { Hanger }\end{array}$ & $6^{\text {th }}$ Guard & $6^{\text {th }}$ Guard & $6^{\text {th }}$ Guard & $6^{\text {th }}$ Guard \\
\hline $\begin{array}{l}\text { St. George's } \\
\text { Guard }\end{array}$ & \begin{tabular}{|c|} 
St. George \\
$\&$ Guard
\end{tabular} & $\begin{array}{c}7^{\text {th }} \text { Guard or } \\
\text { St. George \& } \\
\text { Guard }\end{array}$ & $7^{\text {th }}$ Guard & $7^{\text {th }}$ Guard & $7^{\text {th }}$ Guard & $7^{\text {th }}$ Guard \\
\hline $\begin{array}{c}\text { Medium } \\
\text { Guard }\end{array}$ & - & - & - & - & - & - \\
\hline
\end{tabular}

Table 1: Military Guards of Henry Angelo Junr. 
Although written for a single regiment of volunteers, Hungarian \& Higbland Broad Sword was subscribed to by numerous members of another six regiments of volunteer and yeomanry cavalry. In addition, officers from at least nine regiments of regular cavalry and from a further eleven volunteer, yeomanry, and fencible regiments are listed as subscribers (in addition to some infantry and naval officers and numerous peers of the realm, totalling almost 300 personal subscribers). Hence, the Angelos' amendments to Le Marchant's approved Exercise were widely known amongst the British volunteer cavalry, and to some extent amongst the regulars too. Perhaps crucially, listed amongst the subscribers were the Prince of Wales (later George IV), who only two years before had been instructed by Le Marchant in his own Exercise, ${ }^{11}$ and other important military royals: the Duke of York (Commander-in-Chief) and the Dukes of Kent, Cumberland and Gloucester. ${ }^{52}$ All these men of influence could have not only noted the addition of seven new guards to the 1796 Exercise but also Henry Angelo Snr.'s dedication to Colonel Herries (commander of the Light Horse Volunteers) where he drew direct attention to what he saw as a fundamental flaw in Le Marchant's approved system:

It was your judgement, Sir, which first suggested to the Gentlemen of the very respectable Corps which you command, those improvements upon the Austrian Broad Sword Exercise [Exercise], lately introduced in England, which are submitted to the Public in the following Work: - The system of parrying throughout with the edge, is so obviously preferable, (as well in the Science as the Exercise,) to that of opposing the back or bevil of the sword to the blade of an enemy; that I do not hesitate to hope of it now being universally, as it has already been generally adopted. ${ }^{53}$

Henry Angelo Junr. was, like his father, no stranger to royalty, having taught two sons of George III (Ernest Augustus, the same Duke of Cumberland and later King of Hanover; and Prince Adolphus, Duke of Cambridge $)^{54}$ and it is conceivable that another son of the king, William Duke of Clarence (later William IV), then Admiral of the Fleet had a hand in his next military appointment. Certainly it was "The Lords of the Admiralty" that "having determined that British seamen shall be taught the naval cutlass

\footnotetext{
51 Le Marchant, Memoirs, p. 49.

52 Angelos, Hungarian \& Highland, pp. v-vii.

53 Ibid, pp. ii-iii. Also, in the A Self-Instructor, p. 56, Wilson claims that the parrying with the edge was the official method specified and those regiments that used the back/spine were "contrary to the Commander in Chiefs Regulations" although this is clearly not the method specified in any edition of Exercise. Furthermore, Robert Craig's 1812 version of Exercise proposed for American cavalry is exactly as Le Marchant's version except Craig specifies the parries should be made with the edge. Clearly Angelo was not alone in thinking the parrying with the back/spine was a weakness of Le Marchant's Exercise.

${ }^{54}$ Fare, 'Angelo', p. 155.
} 
exercise, Mr Angelo, jun. has been at Portsmouth drilling the seamen there" 55 and it was to William Duke of Clarence that Henry Angelo Junr. dedicated his Naval Cutlass Exercise. ${ }^{56}$ The same report from The Naval Chronicle claimed "the same practice is also to be introduced into such parts of the army as wear swords" ${ }^{57}$ This process of royal interest in the new sword exercise and its adoption is borne out in other documentary evidence. On 27 May 1816 it was reported in the London Star newspaper that the "Prince Regent and his Royal Highness the Commander-in-Chief [the Duke of York]" went to Buckingham House to see "Mr Angelo, jun." instruct "Officers and Non-Commissioned Officers of the Infantry in the new sword exercise [...] to the satisfaction of the Royal brothers". ${ }^{8}$ By 1 October Angelo's Infantry Sword Exercise; Established by the Prince Regent's Command and dedicated "To Field Marshal His Royal Highness, The Duke of York." was available as a broadside ${ }^{59}$ and by a general order of 1 February 1817 its book form, Rules and Regulations for the Infantry Sword Exercise, was to be issued at a rate of twelve to every battalion of infantry. ${ }^{60}$

\section{1819, REGULATIONS AND INSTRUCTIONS FOR THE CAVALRY SWORD EXERCISE \& ITS OFFICIAL VARIANTS}

The modifications of Hungarian \& Highland Broad Sword as well as other Angelo methods that had been developed and displayed to royalty over the past twenty years, resulting in the 1817 Infantry Sword Exercise of Henry Angelo Junr., were adopted in an official capacity by the British cavalry following a general order from the Commander-in-Chief at the direction of the Prince Regent on 10 June 1819. Here it was stated that Henry Angelo Junr.'s Regulations and Instructions for the Cavalry Sword Exercise "shall be observed and practiced by the several Regiments of Cavalry in His Majesty's Service". ${ }^{61}$

Given this chain of events it was no surprise that Angelo Junr.'s Regulations was markedly different to the 1796 Exercise and instead borrows heavily from Angelo Junr.'s 1817 Infantry Sword Exercise. Hence even the structure of Regulations was different to its official cavalry predecessor. Regulations begins with a 'warm-up' section without swords (Part the First: Section I), followed by the dismounted sword motions being learnt individually (Part the First: Section II); then practiced with partners as attacker and defender (Part the First: Section III); then in dismounted "independent practice" with single-sticks and masks (Part the First: Section IV) in a set sequence of plays termed a "division". Indeed

\footnotetext{
55 The Naval Chronicle, Vol XXXI (1814), p. 115 cited in McGrath \& Barton, British Naval Swords \& Swordsmanship, pp. 94-95.

56 Angelo Junr., Naval Cutlass.

57 The Naval Chronicle, op. cit.

58 'The Army', London Star, May 27 1816, p. 3.

59 Angelo Junr., Angelo's Infantry Sword Exercise.

60 Angelo Junr., Rules and Regulations for the Infantry Sword Exercise.

61 Angelo Junr., Regulations.
} 
the whole of this dismounted section termed "Part the First" (less "Section IV: Practice Drill with Sticks", which does however appear in the subsequent 10 September 1819 version: Regulations and Instructions for the Infantry Sword Exercise) is taken directly from the 1817 Infantry Sword Exercise. "Part the Second" is original and dedicated to the use of the sword when mounted and replicates the dismounted progress from individual mounted drills (Part the Second: Section I) to mounted attack and defence drills with opposition (Part the Second: Section II). "Section III - Practice against Posts" introduces specific targets for mounted use before "Section IV - Practice with the Sticks" sees set divisions performed mounted with opposition, before progressing to "loose play" at increasing speeds.

Yet the 1819 Regulations presented much more profound changes to the 1796 Exercise than merely in terms of structure. In terms of the fundamentals of sword use Regulations was very different. Regulations completely does away with the reliance on wrist cuts, and cuts and guards performed with a straight arm (as in not bending the elbow). Regulations also reassesses the total primacy of the cut over the thrust and, hardly surprisingly given the previous criticism of it by Henry Angelo Snr. in Hungarian \& Highland Broad Sword, rejects Le Marchant's preference for parrying with the back/spine of the blade. Regulations also introduces the concept of circular parries of a nature that Exercise had dismissed as "various circumvolutions of the blade". ${ }^{2}$ Feints performed as "a half cut, or thrust" are only mentioned once in passing in Exercise but are introduced in Regulations and incorporated into both mounted and dismounted drills. ${ }^{63}$ Similarly the pull cut - "drawing of the edge" - or push cut - "forcing [...] the edge" - are introduced and recommend for when the speed of the horse adds impetus or a rider is too pressed for space to cut as normal. ${ }^{64}$

\footnotetext{
62 Le Marchant, Exercise, p. 5.

63 Angelo Junr., Regulations, pp. 43, 29, 64 , 73.

64 Ibid. pp. $74,63$.
} 
ANGELO'S SWORD EXERCISE.
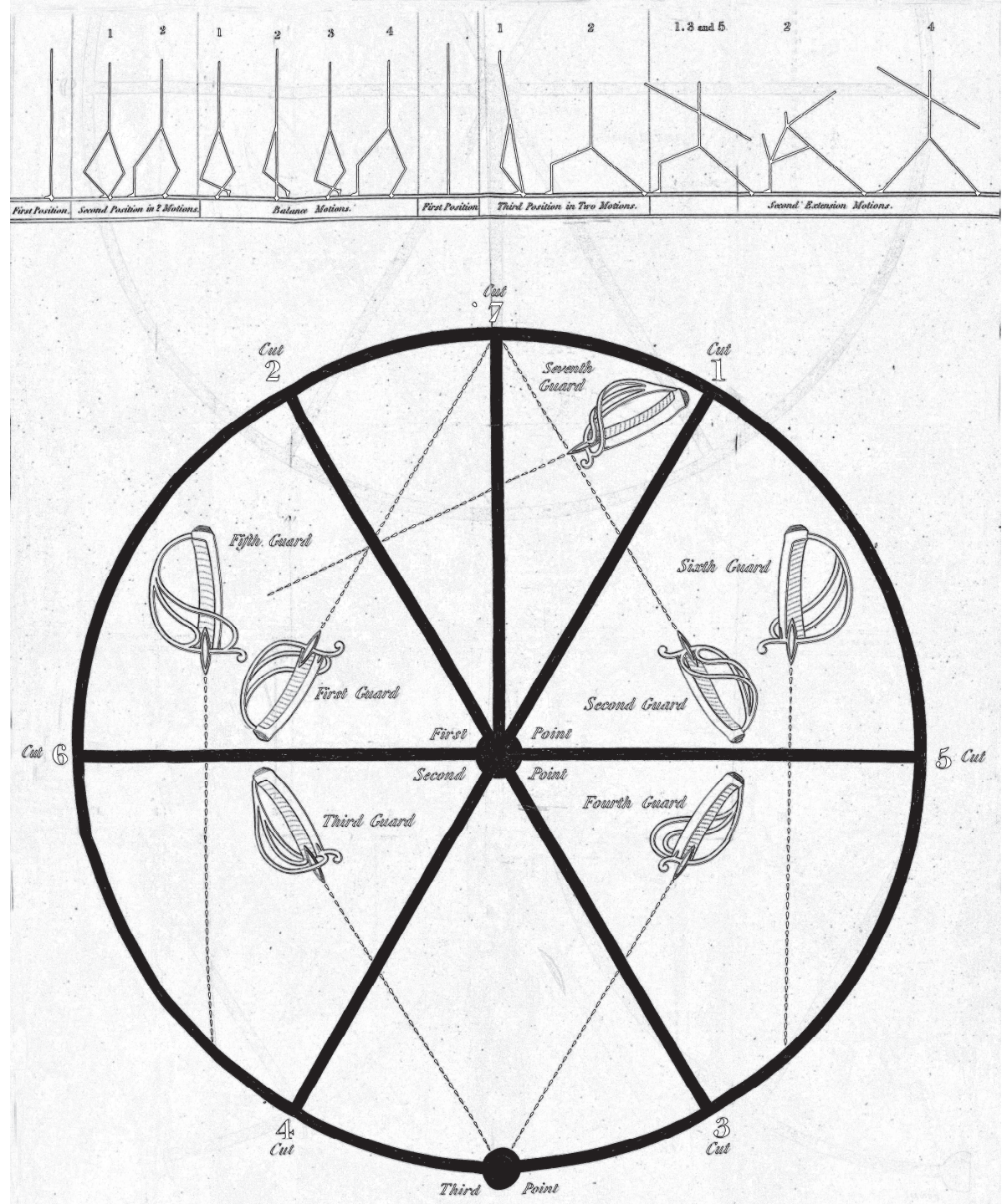

Figure 8: 1819 diagram of “Angelo's Sword Exercise” from Regulations. (C) Royal Armouries.

As its predecessor, and like its infantry equivalent, Regulations relies on a diagram (figure 8) to outline the fundamentals of the system, but other than this diagram, and a depiction of the six "machine posts" for edge and point practice, it is otherwise unillustrated. 
However its main diagram goes into greater details than Exercise, which only outlined the different cuts. The central part of the diagram, "the target", shows seven cuts (the new direction from Exercise being a vertical cut down the centre line), seven numbered guards and three points. Cuts are made along the solid lines, with the guards shown by sword hilts and the broken lines. Of the three points, the first is made from eyelevel to the centre of the target, the hand gripping the sword pronated with the nails down; the second is made to the same target point but from the level of the breast, the hand supinated with the nails up; the third is delivered from hip height towards the lower point target, this time with the nails down. ${ }^{65}$

Instructions for cutting effectively centre on keeping the middle knuckles in line with the edge of the blade and concentrating the acceleration and power of the movement to the final stage of a cut's motion, which should be delivered with the last eight inches of the blade. ${ }^{66}$ Cuts are delivered involving the elbow, in a clear break from Exercise. ${ }^{67}$

In addition to the seven numbered guards there are further defensive actions, absent from the diagram of Regulations, of two parries and three preliminary guards. The two parries are circular: "Left Parry" (a circular, moulinet-type parry bending the wrist and arm forward) and "Right Parry" (bending the wrist and arm back) appear to be the only methods in Regulations that can be used to defend the rider's rear. ${ }^{68}$ The preliminary guards are: "Guard" (figure 9), "Outside Guard" (figure 10) and "Inside Guard", of which the latter is omitted from the mounted section where "Engage" (figure 11) is instead substituted. ${ }^{69}$ Confusingly, these unnumbered guard positions are not considered guards in the sense that the numbered guards are (the numbered guards in fact being what modern readers would consider parries, or what Le Marchant terms "protects"), but merely positions "preparatory to any offensive, or defensive movements" (a modern guard). ${ }^{70}$ This presentation of a "hanging guard" (see table 1 and figure 9) as the main guard position of Regulations, it being taken as the primary preparatory position throughout, ${ }^{71}$ is in stark contrast to Exercise, which warned of the various deficiencies of taking a "hanging guard" as the main guard of a cavalryman. ${ }^{72}$ In the dismounted section these unnumbered guards are used exclusively for engaging an opponent's blade. This practice of engaging an opponent's blade is another element of Regulations not found in Exercise, but as it is only practiced in the dismounted sections of Regulations this is hardly

\footnotetext{
65 Ibid., pp. 19-20.

66 Ibid., p. 13.

${ }^{67}$ Ibid., pp. 17-18.

68 Ibid., pp. 50-51.

69 Ibid., pp. 16-7 48.

70 Ibid., p. 71.

${ }^{71}$ Ibid., pp. 16, 27-35, 48, 55-64.

${ }^{72}$ Le Marchant, Exercise, pp. 15, 80.
} 
surprising as Le Marchant's system was not concerned with dismounted swordsmanship at all.

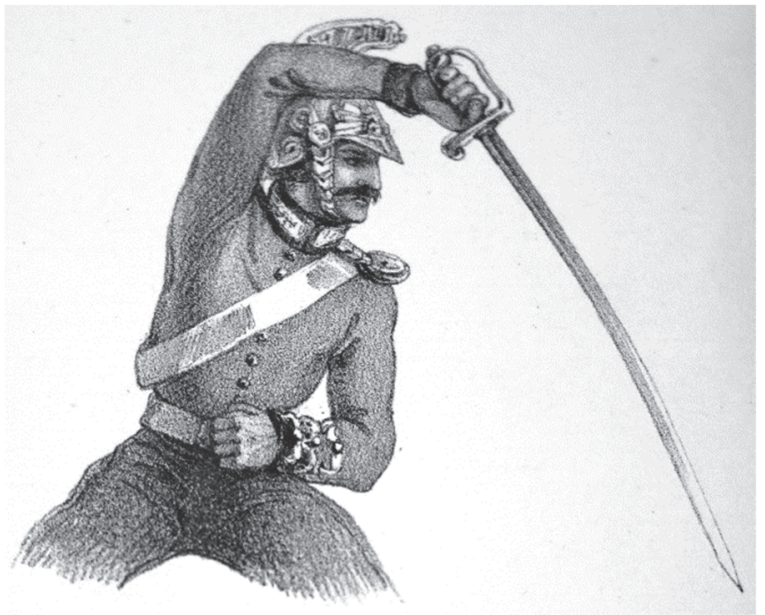

Figure 9: "Left Guard" from the 1835 Yeomanry Instructions. The action is unillustrated in the 1819, 1840 \& 1842/45 Cavalry Sword Exercises but conforms to "Guard" in all those works. It also conforms to the identical actions of "Left Engage" in the 1840 and "Left

Guard" in the 1842/45 versions (see table 1). (C) Royal Armouries.

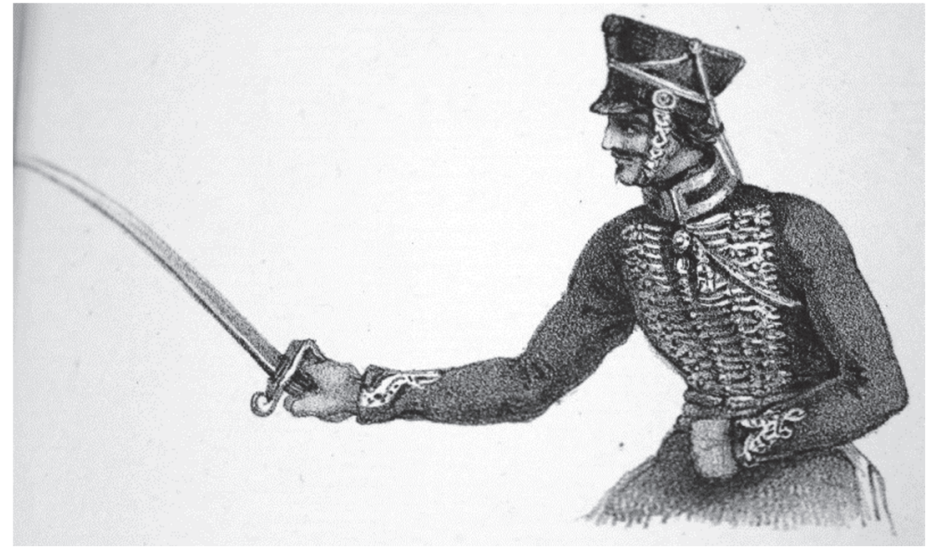

Figure 10: "Right Guard" from the 1835 Yeomanry Instructions. The action is unillustrated in the 1819, 1840 \& 1842/1845 Cavalry Sword Exercises but conforms to "Outside Guard" in all those works. It also conforms to the identical actions of "Right Engage" in the 1840 and "Right Guard" in the 1842/45 versions (see table 1). (C) Royal Armouries. 


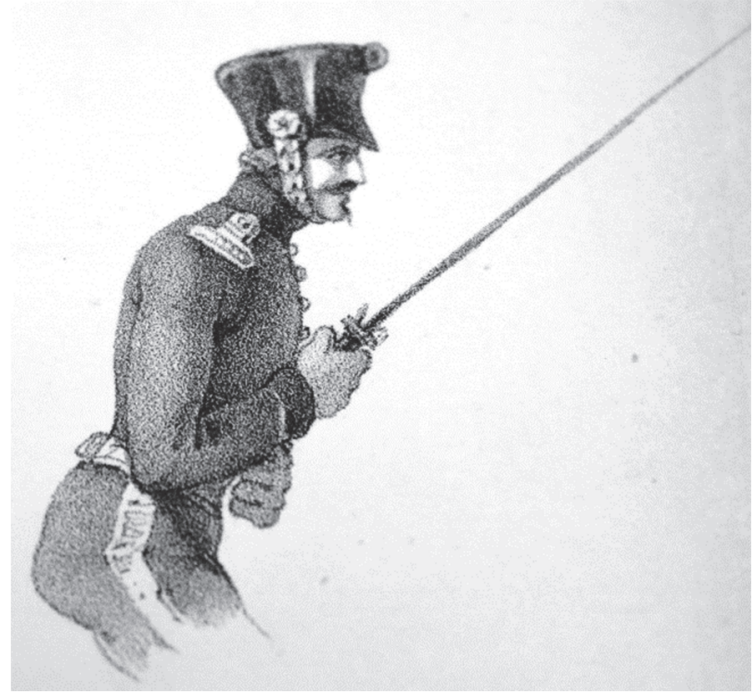

Figure 11: "Engage" from the 1835 Yeomanry Instructions. The body is bent, as pictured, in the 1835 Yeomanry Instructions and 1842/45 Cavalry Sword Exercise. In the 1819 Regulations it is kept square and straight. "Engage" is omitted entirely from the 1840 Exercise. (C) Royal Armouries.

Indeed the amount of space dedicated to dismounted techniques and the similarity between Angelo Junr.'s 1819 Cavalry Sword Regulations and his 1817 Infantry Sword Exercise is telling. For the dismounted sections of the Cavalry Regulations Angelo Junr. has simply copied his Infantry Sword Exercise. This is in spite of the fact that the chance of a cavalryman being expected to fight with a sword when dismounted was remote. Dismounted action, a rare occurrence, was primarily carried out with the carbine, and whilst not all British cavalry carbines of the period were equipped with the ability to take a bayonet (thus perhaps providing one reason why a dismounted cavalryman might have occasional recourse to use his sword on foot) a great deal of Regulations is dedicated to techniques that would only be applicable when fencing on foot; techniques such as lunging, the foot stamp [appel], turning the body to the side and shifting the leg. In addition, all dismounted movements are carried out on foot from the modern fencing en garde position with the right heel in front and directly in line with the left - a position clearly impossible when astride a horse. Only when it comes to the mounted sections is this addressed, with trainees then having to perform all the actions in a very different way: keeping the body square for the cuts, points and the seventh guard; bending from the waist for guards one to six; and starting from the new position of "Engage", which seems to replace the "Inside Guard" when mounted. ${ }^{73}$ These perhaps show Angelo Junr.'s experience as a fencing master rather than a cavalryman in trying to transpose modified dismounted fencing actions into the saddle. The final section before a list of drill commands are outlined,

\footnotetext{
${ }^{73}$ Angelo Junr., Regulations, pp. 48-50.
} 
"General Observations and Directions", similarly devotes space to dismounted fencing and indeed the first three pages can be found verbatim in, published three months later, the 1819 Infantry Sword Exercise. However, the remaining two-thirds of the section are helpfully dedicated to mounted techniques and introduce various cavalry-specific tactics, such as how to best tackle infantry, sword-armed cavalry and, a new threat since Exercise, lancers. ${ }^{74}$

When Regulations was issued the swords carried by the British cavalry were still the 1796 Light and Heavy Cavalry Pattern swords (figures 6 and 7). Angelo Junr. seems to acknowledge this distinction when he speaks of how swords should be held stating: "If the sword is light, the thumb may be placed along the back of the handle; if heavy, the grip of the handle should be held by the thumb and fingers around it". ${ }^{75}$ However Regulations later specify the thumb on the back of the grip for all the unnumbered guards, points, parries and "Engage". ${ }^{76}$ Yet both 1796 Cavalry swords have a short grip not conducive to this kind of thumb position. When the Heavy Cavalry sword is held in this manner the thumb is uncomfortably pressed into the flat guard in front of the hand, or one is forced to hold the sword extremely far back towards the head of the backpiece on the short grip - thus affecting the balance. Whilst the curved rear quillon of the Light Cavalry sword means the thumb can sit more comfortably in this position, the even shorter grip means the sword must be held even further towards its extremity. Furthermore, as the grips of both swords are "shaped for the hand", 77 ideal for the pivoting thumb and forefinger grip of Exercise, when held with the thumb along the back this narrowing of the grip towards the head of the backpiece makes secure gripping with the third and fourth fingers problematic. More obviously, both the 1796 Cavalry swords are quite short weapons with wide, thin, flat blades - far more suited to the cut based system of Exercise they were adopted for.

Hence in the diagram of Regulations a very different hilt is shown (figure 8), that of the French Year IX/XI Light Cavalry Officer's sword - a form that would have suited Angelo's system far better. This may be no coincidence. The Prince Regent (later George IV) had already shown a desire to have his cavalry equipped in a French manner, and by 1816 he had commissioned experimental French-style swords from his cutler John Prosser, apparently intended for issue to his cavalry. ${ }^{7}$ Perhaps Angelo, a man with royal connections, was aware of this by the time he devised the diagram for Regulations?

74 Angelo Junr., Regulations, pp. 74-79. See Larsen \& Yallop, The Cavalry Lance, pp. 4, 6-7, 9, 11, 14, 23-26, for the rise of the lancer in this period.

75 Ibid., p. 13.

76 Ibid., pp. 16-17, 19-20, 22, 48-51.

77 May \& Annis, Swords for Sea Service.

${ }^{78}$ Yallop, Swords of Empire, pp. 88-89. Prosser also supplied a sword similar to both the French Light Cavalry Officer's sword shown in Regulations and the subsequent British 1821 Light Cavalry sword to the Prince Regent in July 1816: Royal Collection Inventory Number 67458: <https://www.rct.uk/collection/search\#/9/collection/67458/sabre> accessed 19 March 2019. 
Certainly the next pattern of Light Cavalry sword bore a resemblance to the French hilt illustrated in Angelo's Regulations. The Pattern 1821 Light (figure 12) and the Heavy Cavalry (figure 13) swords were made by the King's (George IV) cutler Prosser and approved by the King without the knowledge of the Board of Ordnance. ${ }^{79}$ Both new pattern swords had longer, straighter, narrower, thicker, flattened diamond-sectioned blades of more pointed 'cut-and-thrust' type with longer, straighter grips that swell, rather than narrow, at the head of the backpiece - all appropriate changes in light of Angelo Junr.'s new Regulations. These characteristics were similar to the sword that the King also had approved for his $1^{\text {st }}$ Life Guards in 1820 (and possibly also for the $2^{\text {nd }}$ Life Guards, with the Royal Horse Guards adopting a similar form of sword in 1848) with the Pattern 1821 Heavy Cavalry sword essentially being a plainer, slightly shorter and more curved version of the Pattern $18201^{\text {st }}$ Life Guards' sword. ${ }^{80}$

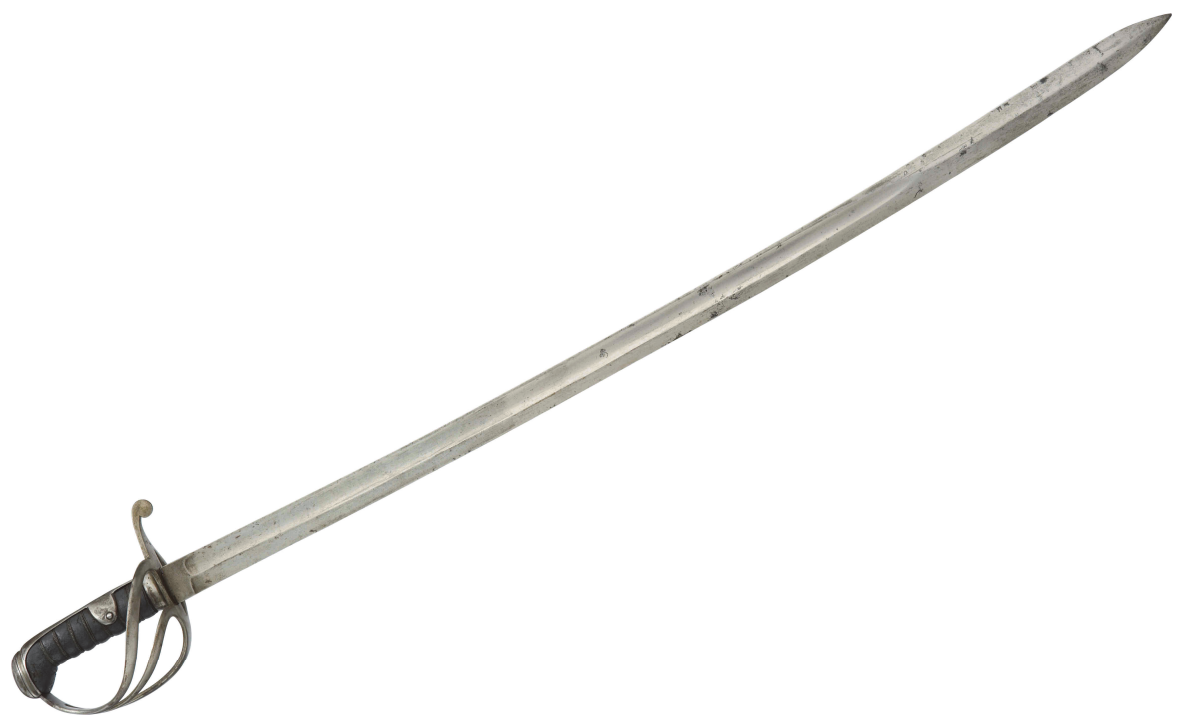

Figure 12: Pattern 1821 Light Cavalry Trooper's sword. Inventory no. IX.347. C Royal Armouries.

\footnotetext{
79 Robson, Swords, p. 24.

80 Ibid., pp. 110-114.
} 


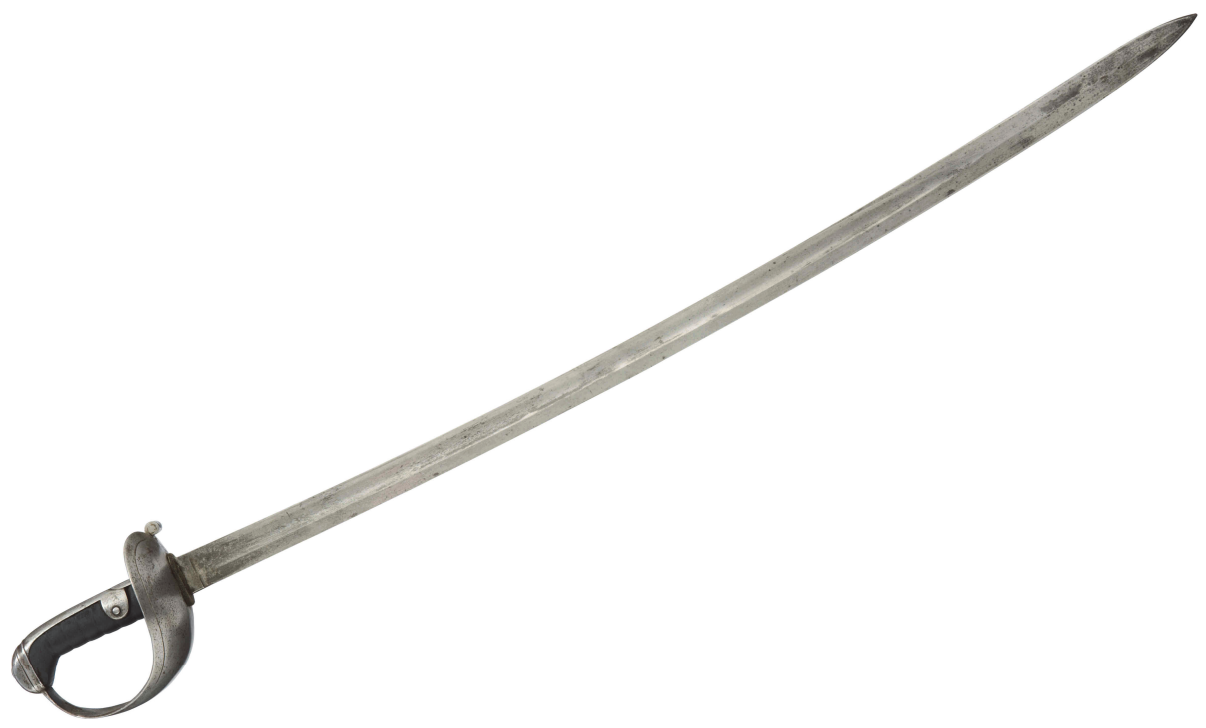

Figure 13: Pattern 1821 Heavy Cavalry Trooper's sword. Inventory no. IX.350. C Royal Armouries.

The 1820 and 1821 Pattern swords would have been more suited to the 1819 Regulations and it is possible that the new swords were in part a response to the new system of swordsmanship, with the adoption of both the new swords and new Regulations seemingly influenced by the King. But despite their date of approval the 1821 swords were not widely issued for some years. In an attempt to use up existing stock of 1796 Pattern swords, production of the 1821 Light Cavalry sword did not begin until March 1823 and the 1821 Heavy Cavalry sword only in 1825. Furthermore, some ten years later all regular regiments had still not received their new swords, with some yeomanry regiments keeping the old pattern until the $1860 \mathrm{~s} .{ }^{81}$ Hence for over ten years, many regiments were using swords ill-suited to the new system of swordsmanship. ${ }^{82}$ Given this long period of using the old swords with the new Regulations, it seems possible that the spear pointing of large numbers of 1796 Heavy Cavalry swords, and some 1796 Light Cavalry swords, may have been an attempt to make these swords better suited to the 1819 Regulations that put more prominence on the thrust, in addition to occurring earlier as a response to facing armoured French cavalry at Waterloo (figure 14). ${ }^{83}$ Such a theory is perhaps tangentially supported by the fact that Radclyffe recommend similar blade re-profiling of both patterns of 1796 Cavalry sword (although his sketches suggested grinding to narrow hatchet points, rather than the spear points more commonly found) for use with his

\footnotetext{
81 Ibid., pp. 26-8.

${ }^{82}$ Even one of the most prestigious regiments, the $10^{\text {th }}$ Hussars, did not receive 1821 Pattern swords until November 1834, see Sumer, 'Trooper I. Harmer', p. 143.

83 Yallop, 'A Sword', pp. 231-232.
} 
thrust-centric $A$ New System of Cavaly Swordsmanship until new, longer, narrower and more pointed swords could be provided. ${ }^{84}$

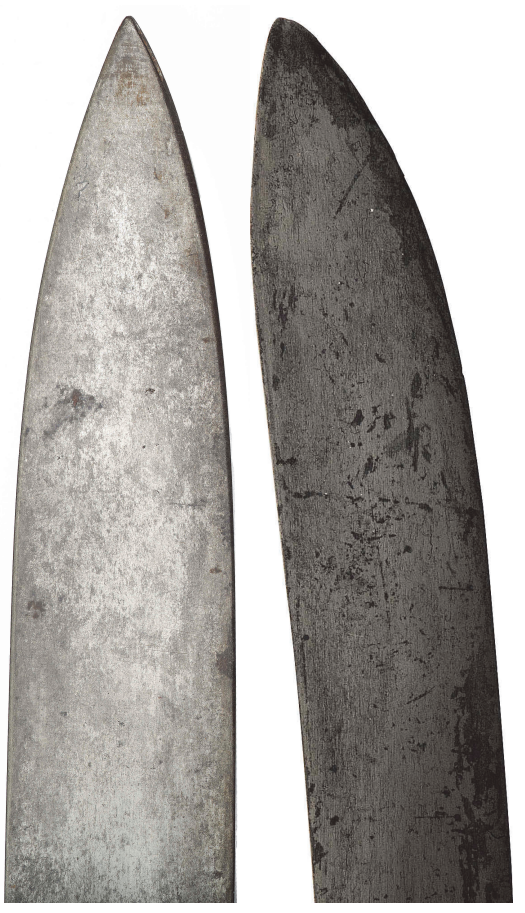

Figure 14: Spear pointed Pattern 1796 Heavy Cavalry (left, IX.8150) and Light Cavalry (right, IX.8014) Trooper's swords. Compare with the unmodified points of figs. 6 and 7. (C) Royal Armouries.

With his sword exercise approved and rolled out, Angelo Junr. was appointed Superintendent of Sword Exercise to the Army in 1833, a position he held for the rest of his life, and in 1835 he privately published a simplified and slightly modified version of Regulations for yeomanry cavalry: Instructions for the Sword Exercise selected from His Majesty's Rules and Regulations, and expressly adapted for the Yeomanry. Whereas Regulations devoted much space to dismounted fencing Instructions only introduces dismounted actions as a preparation for mounted swordsmanship. Hence even when practicing on foot "the men must turn, bend, or stoop, (from the hips only) without twisting the legs, or feet". ${ }^{85}$ This is particularly apparent for the points where the body is bent from the waist in a mounted version of the lunge and during the "Engage" position; whereas in Regulations the body was to be kept square for these actions. ${ }^{86}$ Similarly, as it has no place in the mounted

\footnotetext{
${ }^{84}$ Radclyffe, $A$ New System, pp. $42-3$.

85 Angelo Junr., Instructions, p. 18.

86 Ibid., pp. 10, 9 \& Regulations, pp. 49, 48.
} 
sections of Regulations, the "Inside Guard" is omitted entirely, with Regulation's "Guard" and "Outside Guard" termed "Left Guard" and "Right Guard" respectively in Instructions (see table 1 and figures 9-11). The other significant change to Regulations involves the replacement of the two circular parries of moving the wrist and arm in different directions, "Left Parry" and "Right Parry", with a singular circular "Parry" (bending the wrist and arm forward) carried out on both sides. ${ }^{87}$

Following consultation in 1839 with cavalry officers ${ }^{88}$ a new version of the cavalry sword exercise was approved for the regular cavalry in September $1840^{89}$ which reverted back to some methods from the 1819 Regulations rather than the ones outlined in the 1835 yeomanry Instructions. This might seem natural as, like its 1819 predecessor, the 1840 exercise was an official issue for the regular cavalry rather than privately published for the part-timers of the yeomanry. However, the next two official versions of sword exercise for regular cavalry that followed in quick succession, in 1842 and 1845, instead more closely resembled the 1835 yeomanry version in certain matters than the 1840 version for regulars. Hence of these 1835-45 versions the 1840 exercise alone forbids "the lowering of the head or bending of the body", returning to the erect body position of 1819 for all mounted actions. ${ }^{90}$ Additionally, the 1840 exercise reverts to two circular parries, with the "Left parry" of 1819 being more clearly explained and now termed "First" parry and with the "Right parry" of 1819 termed "Second" parry in 1840. ${ }^{11}$ As in the 1819 version, both of these parries can be carried out on either side. However, perhaps the most peculiar and singular change in the 1840 exercise is the complete omission of "Engage" (figure 11), it being the only cavalry sword exercise of this series to not include it.

Some of these directions from the 1835 yeomanry version resurfaced in subsequent versions of Angelo Junr.'s Cavaly Sword Exercise (approved in April 1842 and very slightly revised for November 1845). "Engage" returned, as did the bending from the waist for the thrusts. The single direction circular parry of the yeomanry version was also reinstated and performed on either side. ${ }^{92}$ In addition some actions were made clearer than in the 1819 or 1840 versions with the grip clearly specified to be with "the thumb and the fingers around it" for all actions apart from some of the points. ${ }^{93}$ Cuts and points are specified as being given from both the wrist and elbow being "given from the wrist to the full

\footnotetext{
87 Angelo Junr., Instructions, p. 12.

88 Greenwood, Cavalry Sword Exercise, p. 6.

89 Angelo Junr., 1840 Cavalry Sword.

90 Ibid., pp. 5, 13-14.

91 Ibid., p. 15.

92 Angelo Junr., 1842 Cavalry Sword, pp. 14-16 \& 1845 Cavalry Sword, pp. 24-26.

93 Ibid., pp. 7, 9, 14, 17, 24. The thumb is on the back of the grip for all the dismounted points, but only "First Point" when mounted, instead being "round the handle" for "Second" and "Third Point".
} 
extent of the arm". ${ }^{94}$ As in the 1840 version, the unnumbered guards (Guard; Inside Guard; Outside Guard) more clearly show their true purpose by being referenced as the "Three Engaging Guards" when dismounted. Confusingly, however, they then are reclassified as "Right Engage" (Outside Guard) and "Left Engage" (Guard) in 1840 and "Right Guard" (Outside Guard) and "Left Guard" (Guard) as in the 1835 Yeomanry manner for the 1842/45 mounted sections (see table 1). ${ }^{95}$ Compared to the 1819 Regulations, the 1840 and 1842/1845 exercises were much reduced and devoid of certain sections of prescribed drills performed in the dismounted en garde position irrelevant to a cavalryman. Similarly the cuts are put in their proper context of cavalry combat, it being made much clearer from the start and throughout that when mounted cuts one, four and five should be delivered on the left and cuts two, three and six on the right - as one would have to when mounted to cut away from the body of the horse, with opponents invariably being engaged not directly to the front but to either side when mounted. ${ }^{96}$

It is possible that some of these changes from the 1819 Regulations were the result of Colonel George Greenwood's recommendations to the president of the board of cavalry officers in 1839, subsequently published in April 1840 as A Cavalry Sword Exercise and dedicated to the Commander-in-Chief Rowland Hill. ${ }^{97}$ Some of the more obvious changes Greenwood recommended, such as the problems of translating an infantry sword exercise into the saddle where it must be "learnt anew" for mounted use, are addressed in the 1840 and 1842/45 exercises with their much reduced dismounted sections and increased focus on cavalry action..$^{98}$ Perhaps most compelling regarding the possible influence of Greenwood on these changes is that the subsequent 1840 exercise omits Angelo's "Engage" position, which Greenwood recommended be discarded as "useless". ${ }^{99}$ Yet as the board of cavalry officer's had met in 1839 to consider the "revision, simplification and curtailment of the Sword Exercise" it seems more likely such amendments in the 1840 and 1842/45 exercises were more the result of the board's previous recommendation and those fourteen regiments that tested the 1839 amendments until March 1840, rather than a result of Greenwood's suggestions. ${ }^{100}$ Certainly many of Greenwood's other recommendations for changes from the 1819 Regulations (the reduction to a "Quarte and Tirece" system; the omission of "Left Guard"; the removal of Angelo's target, stick drill on foot or independent mounted practice and

\footnotetext{
94 Ibid, p. 11, 19

95 Angelo Junr., 1840 Cavalry Sword, pp. 15-17 \& Ibid., pp. 11, 13, 19, 22-3.

96 Ibid., pp. 17-18, 21 \& pp. 13-4, 17, 23-4, 27.

97 Greenwood, Cavalry Sword Exercise, pp. 5-7.

98 Ibid., pp. 14-15.

99 Ibid., p. 19.

100 Ibid., p. 6.
} 
the insistence that cavalry should train to use swords in their left hand too for when engaged on the near side ${ }^{101}$ ) find no place in either the 1840 or 1842/45 exercises.

Hence, despite a slight increase in clarity, brevity, and proportionally more effort devoted to mounted combat, the 1840 and 1842/45 exercises remained fundamentally the same as Regulations and should be seen as a slight refining, rather than replacement, of their 1819 predecessor. Hence Angelo Junr.'s system of cavalry swordsmanship can be said to have been the official one of the British cavalry for almost 40 years, continuing in use for another six years in this form after the author's death in 1852.

During this time these exercises were widely practiced, being incorporated into drills and parades. ${ }^{102}$ Although used in action in numerous wars in India, Afghanistan, Burma and Sindh, in terms of assessing its military effectiveness perhaps the clearest example of its use in action came at the end of the period during the charge of the Heavy Brigade at Balaclava (25 October 1854). Although Russian inaction and a British flank attack probably had at least as much to do with the charge's ultimate success, the role of cavalry swordsmanship should not be dismissed as this "charge" was carried out at no more than a trot. Without having the momentum of the charge to win the combat on contact, the fact that British proceeded to best their considerably more numerous opponents for ten minutes of melee whilst suffering very few casualties before routing them can perhaps be taken as some vindication of Angelo Junr.'s drill, or at least the British cavalry's competence in it. ${ }^{103}$ It seems Angelo's "Cut 7" was particularly effective; doctors tending the wounded remarked upon the number of Russian dead who "had their head-dress and skull divided down to the chin" with cuts being given more frequently as, despite good thrusts being landed, it was sometimes difficult to penetrate the Russians' greatcoats with the point. ${ }^{104}$ That the success of this action may have been in part due to the sword exercise is reinforced by the adherence cavalry regiments paid to it. After the charge a doctor asked a British Dragoon how he came by his head wound. So indoctrinated was he by the set plays he knew he said "I had just cut 5 at a Russian, and the damned fool never guarded at all, but hit me over the head"'!105

\section{CONCLUSION}

During the period discussed in this article the British cavalry underwent considerable change with regards to their swordplay and swords. They went from employing a range of swords with unknown and presumably greatly varied techniques and levels of effectiveness to using an official, recorded, and heavily prescribed method of swordplay with apparent success; albeit neither the swords nor systems of swordsmanship were

101 Ibid., pp. 9, 19, 14, 20, 22-3.

102 Anon., East India Company's, p. 84.

103 Anglesey, A History, pp. 67-77.

104 Sir Evelyn Wood, The Crimea in 1854 and 1894, p. 113, cited in Robson, Swords, p. 32.

105 Anglesey, A History, pp. 72-3. 
totally free from criticism. Towards the end of the period all troopers of regular regiments were even carrying out such actions with the same sword, the universal Pattern 1853 Cavalry sword having started to be issued to both Light and Heavy regiments - bringing even greater homogeneity to the swords of the British cavalry and their use.

During the next sixty years rapid advances in weapons technology would see significant changes in warfare, with the role of sword-armed cavalry being called into question. However, for the first half of the nineteenth century, military technology remained comparatively static, with the battlefield importance of sword-armed and drilled cavalry beyond any doubt. Hence fundamental changes in systems of swordsmanship, and the swords to be used with such systems, were sought in attempts to improve performance in this vital area of the cavalry's military function - engaging the enemy in close combat with the sword.

\section{BIBLIOGRAPHY}

\section{VII.1. Primary sources}

Adjutant General's Office, Rules and Regulations for the Cavalry, (London: J. Walter, 1795)

Anon., 'The Army', London Star, 27 May 1816, p. 3, Online:

$<$ https://newspaperarchive.com/london-star-may-27-1816-p-3/>, accessed 18

February 2019

Anon, 'The East India Company's Military Seminary', in The United Service Journal and Naval and Military Magazine (1830 part I), pp. 83-84, Online:

$<$ https:/ $/$ babel.hathitrust.org/cgi/pt?id=hvd.hw27yf;view=1up;seq $=78>$, accessed 13 March 2019

Henry Angelo Junr., illustrated by J.A. Atkinson, Angelo's Infantry Sword Exercise; Established by the Prince Regent's Command, (London: W. Clowes, 1816), Online: $<$ https://www.jamescumminsbookseller.com/pages/books/251892/fencingbroadside/angelos-infantry-sword-exercise-established-by-the-prince-regentscommand >, accessed 18 February 2019

[Henry Angelo Junr.], Cavalry Sword Exercise, 1840 (London: Adjutant General's Office, 1840)

[Henry Angelo Junr.], Cavalry Sword Exercise, 1842 (London: Adjutant General's Office, 1843)

[Henry Angelo Junr.], Cavalry Sword Exercise, 1845 (London: Adjutant General's Office, 1845)

Henry Angelo Snr. \& Henry Angelo Junr., illustrated by Thomas Rowlandson, Hungarian \& Highland Broad Sword (London: H. Angelo, 1799)

Henry Angelo Junr., Instructions for the Sword Exercise selected from His Majesty's Rules and Regulations, and expressly adapted for the Yeomanry (London: W. Clowes, 1835) 
Henry Angelo Junr., illustrated by Thomas Rowlandson, Naval Cutlass Exercise including Prepatory Movements and Words of Command (London: T. Egerton, 1813), Online $<$ https://collections.rmg.co.uk/collections/objects/147422.htmll>, accessed 13 February 2019

[Henry Angelo Junr.], Rules and Regulations for the Infantry Sword Exercise (London: Adjutant General's Office, 1817)

[Henry Angelo Junr.], Regulations and Instructions for the Cavalry Sword Exercise (London: Adjutant General's Office, 1819)

Philip Astley, Remarks on the Profession and Duty of a Soldier; With Other Observations Relative to the Army, at This Time in Actual Service on the Continent (London: P. Astley, 1794), Online: <https://books.google.co.uk/books/about/Remarks on the Profession a nd Duty of a.html?id $=$ MFXAAAAcAAJ\&redir esc $=\mathrm{y}>$, accessed 13 November 2018

Humphrey Bland, A Treatise of Military Discipline, in which is laid down and explained the duty of the officer and soldier thro' the several branches of the service, $5^{\text {th }}$ Edition (London: John and Paul Knapton, 1743),

Online: <https://books.google.co.uk/books/about/A Treatise of Military Discipli ne.html?id $=\mathrm{xHtUAAAAYAAJ \& redir}$ esc $=_{\mathrm{Y}}>$, accessed 27 November 2018

William Bragge, Peninsular Portrait 1811-1814: The letters of Captain William Bragge, Third (King's Own) Dragoons, ed. by S.A.C Cassels (London: Oxford University Press, 1963)

Robert Craig, Rules and regulations for the sword exercise of the cavaly: to which is added, the rules for drill, and the evolutions of the light cavalry (Baltimore: R. Craig, 1812)

Robert Hinde, The Discipline of the Light Horse (London: W. Owen, 1778), Online: <https://books.google.co.uk/books/about/The_Discipline_of_the_Light_ horse.html?id=jB5EAAAAYAAJ>, accessed 27 November 2018

Andrew Lonnergan, The Fencer's Guide (London: A. Lonnergan, 1771), Online: $<\underline{\text { https://books.google.co.uk/books?id=4fMIAAAAQAAJ\&printsec=frontc }}$ over\&source $=$ gbs ge summary $\mathrm{r} \& \mathrm{cad}=0 \mathrm{\#}_{\mathrm{v}}=$ onepage $\& \mathrm{q} \& \mathrm{f}=$ false $>$ accessed 1 February 2019

Denis Le Marchant, Memoirs of the late Major-General Le Marchant (London: the author, 1841; repr. Uckfield: The Naval \& Military Press, 2006)

[John Gaspard Le Marchant], Rules and Regulations for the Sword Exercise of the Cavaly (London: Adjutant General's Office, 1796; repr. Uckfield: The Naval \& Military Press, 2009)

George Greenwood, A Cavaly Sword Exercise (London: W. Clowes, 1840), Online: $<$ https://play.google.com/books/reader?id=UNODAAAAQAAJ\&hl=en\&p $\mathrm{g}=$ GBS.PA6 $>$, accessed 18 March 2019

Charles Parquin, The Military Memoirs of Charles Parquin. Charles Parquin, ed. by B.T. Jones (London: Greenhill, 1969)

Charles Edward Radclyffe, $A$ New System of Cavaly Swordsmanship, ed. by Gareth Glover \& Paul Morrison (Huntingdon: Ken Trotman Publishing, 2019) 
S. Waymouth, '2nd Life Guards', in Waterloo Letters, ed. by H.T. Siborne (London: Cassell, 1891; repr. London: Greenhill, 1993)

Thompson Wilson, A self-instructor of the new system of cavalry and infantry sword exercise; with instructions for the old sword exercise, and its attack and defence; together with directions and some useful remarks on the lance exercise, (Manchester: T. Wilson, 1822), Online: <https://books.google.co.uk/books/about/A Self instructor of the New System_of_C.html?id=o2SWmA-2D0cC\&redir_esc $=y>$, accessed 26 March 2019

\section{VII.2. Secondary literature}

Anglesey, Marquess of, A History of the British Cavalry 1816-1919, Volume 2: 1851-1871 (London: Leo Cooper, 1975; repr. 1989)

Aylward, J.D., The House of Angelo: A Dynasty of Swordsmen (London: Batchworth Press, 1953)

Defence Academy of the United Kingdom, 'Major-General John Gaspard Le Marchant (1766-1812)., Online: <https://www.da.mod.uk/publications/hobson-libraryjscsc/artwork/major-general-john-gaspard-le-marchant-1766-1812> accessed 20 November 2018

Fare, Malcolm, 'Domenico Angelo', in Oxford Dictionary of National Biography, Volume 2, ed. by H.C.G Matthew \& Brian Harrison (Oxford: Oxford University Press, 2004), pp. $154-155$

Field, Andrew W., Waterloo: The French Perspective. (Barnsley: Pen \& Sword Books, 2012)

Fletcher, Ian, Galloping at Everything: The British Cavalry in the Peninsular War and at Waterloo, 1808-15 - A Reappraisal (Staplehurst: Spellmount, 1999)

J.M., 'On the actions and the merits of the French and English Cavalry', The United Service Journal and Naval and Military Magazine, (1831 part III), pp. 248-52, Online: < https://babel.hathitrust.org/cgi/pt?id=uc1.b2991729;view=1up;seq=266> , accessed 23 January 2019.

Larsen, Alan \& Yallop, Henry, The Cavalry Lance (Oxford: Osprey, 2017)

McGrath, John \& Barton, Mark, British Naval Swords \& Swordsmanship (Barnsley: Seaforth Publishing, 2013)

May, W.E., \& Annis, P.G.W., Swords for Sea Service, 2 Vols (London: HMSO, 1970)

Muir, Rory, Tactics and the Experience of Battle in the Age of Napoleon (London: Yale University Press, 1998)

Robson, Brian, Swords of the British Army: The Regulation Patterns, 1788 to 1914, Revised Edition (London: National Army Museum, 1996)

Thoumine, R.H., Scientific Solider: A Life of General Le Marchant, 1766-1812 (London: Oxford University Press, 1968)

Sumner, Percy, 'Trooper I. Harmer, 10'th Hussars, circa 1833', in Journal of the Society for Army Historical Research,25/104 (1947), p. 143 
Vindex, 'Actions of the British Cavalry', The United Service Journal and Naval and Military Magazine, (1831 part II), pp. 357-63 and 522-30,

Online: $<$ https:/ $/$ babel.hathitrust.org $/$ cgi/pt?id=chi.096668058; view=1up;seq=7>, accessed 1 February 2019

Yallop, Henry, 'A Sword for a System: The Pattern 1796 Light Cavalry Sword', in The The Sword: Form and Thoughts. Proceedings of the second Sword Conference 19/20 November 2015, Deutsches Klingenmuseum Solingen, ed. by Lisa Deutscher, Mirjam Kaiser and Sixt Wetzler (Woodbridge: Boydell and Brewer), pp. 216-235

Yallop, Henry, 'Swords of Empire: The 19th Century Frenchification of European Edged Weapons', in The Ambassadors of Dialogue: The Role of Diplomatic Gifts and Works of Arts and Crafts in Intercultural Exchange. Papers from the International Conference of the International Committee for Museums and Collections of Arms and Military History (ICOMAM) and the International Committee for Museums Collections of Decorative Arts and Design (ICDAD) at the National Museum in Krakow 16th-18th of September, 2015, ed. by Michał Dziewulski (Krakow: ICOMAM, 2016), pp. 81-94 